\title{
Injection heights of springtime biomass-burning plumes over peninsular Southeast Asia and their impacts on long-range pollutant transport
}

\author{
Y. Jian and T.-M. Fu \\ Laboratory for Climate and Ocean-Atmosphere Studies, Department of Atmospheric and Oceanic Sciences, School of \\ Physics, Peking University, Beijing, 100871, China \\ Correspondence to: T.-M. Fu (tmfu@ pku.edu.cn)
}

Received: 13 August 2013 - Published in Atmos. Chem. Phys. Discuss.: 10 September 2013

Revised: 2 March 2014 - Accepted: 9 March 2014 - Published: 22 April 2014

\begin{abstract}
We analyzed observations from the Multi-angle Imaging SpectroRadiometer (MISR) to determine the injection heights of biomass-burning smoke plumes over peninsular Southeast Asia (PSEA, here defined as Vietnam, Cambodia, Thailand, Laos, and Myanmar) in the spring, with the goal of evaluating the impacts on long-range pollutant transport. We retrieved the heights of 22000 MISR smoke pixels from 607 smoke plumes over PSEA during February to April of the years 2001-2010. Forty-five percent of the analyzed smoke pixels were above the local mean boundary layer $(1 \mathrm{~km})$ at MISR overpass time (10:30 a.m. local time). We used the GEOS-Chem model to simulate the transport of PSEA biomass-burning pollutants in March 2001. On a monthly mean basis, we found that the direct injection of $40 \%$ of the PSEA biomass-burning emissions had little impact on the long-range transport of $\mathrm{CO}$ to downwind regions, compared to a control simulation where all biomass-burning emissions were released in the boundary layer. This was because $\mathrm{CO}$ at the surface over PSEA was efficiently lifted into the free troposphere by deep convection associated with synoptic-scale weather systems. For pollutants with lifetimes shorter than the synoptic timescale, such as black carbon aerosol (BC), their long-range transport was much more sensitive to the initial plume injection height. The direct injection of $\mathrm{NO}_{\mathrm{x}}$ from PSEA biomass burning into the free troposphere drove increased formation and transport of peroxyacetyl nitrate (PAN), which in turn led to a small increase in ozone over downwind southern China and the northwestern Pacific. The Pacific subtropical high transported BC emitted from PSEA biomass burning to the marine boundary layer
\end{abstract}

over the tropical northwestern Pacific. We compared our model results to aircraft measurements over the northwestern Pacific during the TRACE-P campaign (March 2001). The direct injection of $40 \%$ of the PSEA biomass-burning pollutants into the free troposphere in the model led to a more pronounced BC peak at $3 \mathrm{~km}$ over the northwestern Pacific. Our analysis highlights the point that the injection heights of smoke plumes presents great uncertainty over the interpretation of $\mathrm{BC}$ measurements downwind of biomass-burning regions.

\section{Introduction}

Open burning of biomass emits large amounts of trace gases and aerosols into the atmosphere, affecting atmospheric chemistry and climate. Buoyed by the thermal energy of fire and local atmospheric instability, biomass-burning smoke plumes can sometimes rise above the boundary layer and inject directly into the free troposphere, affecting the longrange transport efficiency of the emitted pollutants (e.g., Colarco et al., 2004; Fromm et al., 2005; Damoah et al., 2006). Over Peninsular Southeast Asia (PSEA, here defined as Vietnam, Cambodia, Thailand, Laos, and Myanmar), heavy biomass burning occurs annually in the spring (February to April) due to slash-and-burn and land-clearing practices before the local growing season (Fox et al., 2009). Here we analyzed space-based observations to determine the injection heights of biomass burning smoke plumes over PSEA in the spring, as well as assessed their impacts on the long-range 
transport of pollutants and the formation of ozone in downwind regions.

The pollutants emitted from PSEA biomass burning in the spring can be transported by the prevailing westerly wind to affect the air quality and chemistry over downwind southern China and the northwestern Pacific. Surface and ozonesonde measurements in southern China in the spring showed significant enhancements in $\mathrm{CO}$, black carbon aerosol (BC), $\mathrm{PM}_{2.5}, \mathrm{PM}_{10}$, and ozone when the local air was impacted by air masses back-traceable to PSEA (Liu et al., 1999; Chan et al., 2000; Deng et al., 2008; Lin et al., 2009, 2010; Yen et al., 2012). Using a regional model, Fu et al. (2012) found that the long-range transport of PSEA biomass-burning emissions during spring 2006 contributed significantly to the monthly mean surface concentrations of CO (20-50\%), ozone (10$30 \%$ ), and $\mathrm{PM}_{2.5}(10-70 \%)$ in southern China, as well as leading to 2-5 ppbv ozone enhancement in the lower troposphere over the western Pacific. Aircraft measurements along the Pacific Rim during the Transport and Chemical Evolution over the Pacific (TRACE-P) campaign in spring 2001 characterized the outflow of biomass-burning pollutants from PSEA to the northwestern Pacific (Jacob et al., 2003). Over the northwestern Pacific, back trajectories showed that $45 \%$ and $60 \%$ of the air masses sampled by TRACE-P aircraft at 2-4 km and 4-8 km altitude, respectively, were transported from PSEA (Kondo et al., 2004). Model simulations showed that the PSEA biomass-burning pollutants were lifted from the surface near their source region by deep convection. These pollutants were then transported along the warm conveyor belts ahead of cold fronts to the northwestern Pacific at altitudes above $2 \mathrm{~km}$ (Carmichael et al., 2003; Liu et al., 2003; Miyazaki et al., 2003; Lin et al., 2009).

Model studies showed that direct injection of biomass burning pollutants into the free troposphere generally leads to enhanced long-range transport, due to faster transport by the stronger winds and/or prolonged lifetime of the pollutants in the free troposphere (Leung et al., 2007; Chen et al., 2009). The standard treatment in most large-scale chemical transport models has been to release biomass-burning emissions in the boundary layer (e.g., Bey et al., 2001). Leung et al. (2007) and Turquety et al. (2007) simulated the transport of $\mathrm{CO}$ from summertime boreal forest fires. Both studies found that injecting $60 \%$ of the biomass burning emissions directly into the free troposphere in the model improved agreement with downwind CO surface and column measurements, compared to simulations where biomass-burning emissions were released only in the boundary layer. Several studies embedded high resolution models or parameterization schemes to resolve the plume-rising process in largescale chemical transport models (Freitas et al., 2006, 2007; Rio et al., 2010). These studies also found that the injections of biomass-burning emissions into the free troposphere have a large impact on CO concentrations downwind (Freitas et al., 2006, 2007). Conversely, Chen et al. (2009) found that the injection heights of North American boreal fire emis- sions had limited impacts on $\mathrm{CO}$ concentrations over the downwind areas in North America. They attributed this lack of sensitivity to frequent strong convective activities occurring along the transport pathway, which would lift $\mathrm{CO}$ into the free troposphere regardless of the initial injection height. However, they showed that the long-range transport of $\mathrm{BC}$ was much more sensitive to injection height, owing to the shorter lifetime of BC compared to $\mathrm{CO}$.

Space-based remote sensing, such as images from the Multi-angle Imaging SpectroRadiometer (MISR) and backscatter measurements from the Cloud-Aerosol Lidar with Orthogonal Polarization (CALIOP), can be used to determine the injection heights of biomass-burning smoke plumes (e.g., Kahn et al., 2007, 2008; Labonne et al., 2007). Height-retrieval studies using MISR images showed that the injection heights of smoke plumes associated with summertime North American forest fires ranged from a few hundred meters to $5 \mathrm{~km}$ (Mazzoni et al., 2007; Kahn et al., 2008; Val Martin et al., 2010). Analyses of CALIOP backscattering measurements of smoke plumes from summertime European forest fires similarly found injection heights of $1.6-5.9 \mathrm{~km}$ (Amiridis et al., 2010). However, Labonne et al. (2007) analyzed CALIOP backscatter measurements over 8 major biomass burning regions over the world during July-August 2006. They found that the injection height for most smoke plumes were within the boundary layer, especially in the tropics. Studies indicated that the injection heights of smoke plumes are sensitive to the type of biomass burned, the thermal power of the fire, and the atmospheric stability structure at the burning site (Ferguson et al., 2003; Mims et al., 2010; Val Martin et al., 2010, 2012; Tosca et al., 2011; Zender et al., 2012).

In this study, we analyzed satellite observations over PSEA in the spring during the years 2001 to 2010 to determine the injection heights of biomass burning smoke plumes. We applied the resulting probability distribution of smoke plume injection heights to a chemical transport model to assess the impacts on the long-range transport of pollutants to downwind southern China and the northwestern Pacific. We compared model results against aircraft measurements during the TRACE-P campaign in spring 2001 to further examine the impacts on long-range transport and the interpretation of measurements.

\section{Data and methodology}

\subsection{Fire observation from MISR and MODIS, and smoke plume identification using MINX}

We used a two-step approach to extract MISR observations of biomass-burning smoke plumes over PSEA in the spring during the years 2001 to 2010. We first used the Level 2 thermal anomalies product from the Moderate Resolution Imaging Spectroradiometer (MODIS) instrument (MOD14) 
(Giglio et al., 2003) to locate possible open fires over PSEA during this period. We then extracted the MISR scenes intersecting these thermal anomalies to screen for smoke plumes.

Both MODIS and MISR are onboard the NASA Terra satellite, which overpasses the equator in the descending mode at approximately 10:30 a.m. local time. The cross-track swath width of MODIS is $2330 \mathrm{~km}$, such that global coverage is achieved every one to two days. MODIS has 36 spectral channels with wavelengths between $0.4 \mu \mathrm{m}$ and $14.2 \mu \mathrm{m}$. Thermal anomalies are detected at $1 \mathrm{~km}$ spatial resolution (nadir) using the brightness temperatures derived from the $4 \mu \mathrm{m}$ and $11 \mu \mathrm{m}$ channels (Giglio et al., 2003).

The MISR instrument (Diner et al., 1998) consists of nine push-broom cameras placed at viewing angles from $-70.5^{\circ}$ to $70.5^{\circ}$ (relative to nadir) in line with the ground track. Each camera acquires data at four wavelengths: $446 \mathrm{~nm}, 558 \mathrm{~nm}$, $672 \mathrm{~nm}$, and $866 \mathrm{~nm}$. The cross-track width of the MISR swath, common to all nine cameras, is $360 \mathrm{~km}$, such that global coverage is achieved every nine days at the equator. The horizontal resolution is $275 \mathrm{~m}$ in the red band for all nine cameras and in all four bands for the nadir camera. The horizontal resolution for the remaining 24 bands is $1.1 \mathrm{~km}$.

We manually screened for smoke plumes with the aid of the MISR INteractive eXplorer software (MINX) developed by the Jet Propulsion Laboratory (Nelson et al., 2008, 2013). MINX combines the four spectral bands to form a highresolution true-color image for each of the nine cameras on MISR, and the resulting nine images can be animated. We used this animation, superimposed with the MODIS thermal anomalies, as a visual aid to subjectively identify smoke plumes. Our criteria for identifying a biomass-burning smoke plume were: (1) a plume-shaped area of high reflectivity was visible from the MINX animation; (2) that high-reflectivity area showed a shift in position relative to the surface between cameras, indicating that it was above the surface; and (3) the vertex of that high-reflectivity area was marked by one or more MODIS thermal anomalies. We manually determined the boundary and surface origin of the smoke plume, as well as the local wind direction, using the animation.

\subsection{Smoke pixel height retrieval using MINX}

We used the stereoscopic algorithm in MINX to retrieve the heights of the individual smoke pixels in the identified smoke plumes. Stereo-height retrieval is based on the shifts of pixels relative to the surface between cameras (Nelson et al., 2008, 2013). The MINX height retrieval algorithm uses data from the seven inner cameras on MISR, instead of using data from only the three center cameras as does the standard MISR height retrieval algorithm (Moroney et al., 2002). Also, MINX allows its users to specify the wind direction over the targeted area to better account for advection during the time lapses between cameras. The height of each smoke pixel was defined relative to the terrain directly underneath that smoke pixel. For most smoke pixels, we used the wind-corrected stereo-height retrieved by MINX. However, the wind correction factor could not be calculated for pixels less than $226 \mathrm{~m}$ above the local terrain or in scenes where the wind direction was within $15^{\circ}$ of the instrument track. In such cases, we used the zero-wind stereo-height retrieval instead. The differences between wind-corrected stereo-height and zero-wind stereo-height were almost always within $500 \mathrm{~m}$. Only $2 \%$ of all the analyzed pixels had wind-corrected stereo-heights and zero-wind stereo-heights differing by more than $1 \mathrm{~km}$, and these pixels were not excluded from the analysis. The horizontal and vertical resolutions for the pixel stereo-height retrieved by MINX were $1.1 \mathrm{~km}$ and $275 \mathrm{~m}$, respectively (Nelson et al., 2013).

\subsection{Land cover data}

We used the MODIS Level 3 land cover product (MOD12Q1 - Friedl et al., 2010) to determine the type of land cover associated with each of the identified smoke plumes. This product was derived from a year of MODIS observations from both the Terra and Aqua platforms and contained the 17 International Geosphere-Biosphere Programme (IGBP) land cover classes. The horizontal resolution of the land cover data set was $0.5 \mathrm{~km}$.

\subsection{Model simulations}

We used the GEOS-Chem global chemical transport model to simulate the transport of biomass-burning pollutants from PSEA during spring 2001. GEOS-Chem (version 9.1.2; http: //acmg.seas.harvard.edu/geos) was driven by the assimilated meteorological data (MERRA) from the Goddard Earth Observing System (GEOS) of the NASA Global Modeling Assimilation Office (Bey et al., 2001). The native resolution of the meteorological data was $0.67^{\circ}$ longitude $\times 0.5^{\circ}$ latitude, with 72 levels extending from the surface to $0.01 \mathrm{hPa}$. To drive our simulation, the horizontal resolution was reduced to $2.5^{\circ}$ longitude $\times 2.0^{\circ}$ latitude. Vertical levels were reduced to 47 levels, with 8 levels in the lowest $1 \mathrm{~km}$ and 14 levels between $1 \mathrm{~km}$ and $5 \mathrm{~km}$. Meteorology fields were updated in the model every $3 \mathrm{~h}$ (every $1 \mathrm{~h}$ for surface quantities and planetary boundary layer depths, and every $6 \mathrm{~h}$ for instantaneous fields). The chemistry scheme in GEOS-Chem was as described in Bey et al. (2001) and Mao et al. (2010). Turbulent mixing within the boundary layer was assumed to be full and instantaneous (Bey et al., 2001). We conducted a sensitivity simulation using a non-local boundary layer mixing scheme (Lin and McElroy, 2010) but found that it had little impact on the results reported below in Sects. 4 and 5. Convective transport was computed from the convective mass fluxes in the meteorological fields, as described by Wu et al. (2007). Dry deposition was based on Wesely (1989) as implemented by Wang et al. (1998). Wet deposition was as described by Liu et al. (2001). Freshly emitted BC was assumed to be $80 \%$ hydrophobic and $20 \%$ hydrophilic, with a conversion timescale 
Table 1. Annual biomass burning and anthropogenic emissions from PSEA ${ }^{\mathrm{a}}$ and from the entire East and South Asia ${ }^{\mathrm{b}}$.

\begin{tabular}{|c|c|c|c|c|}
\hline & \multicolumn{2}{|c|}{$\begin{array}{l}\text { Biomass } \\
\text { burning }\end{array}$} & \multicolumn{2}{|c|}{$\begin{array}{c}\text { Anthropogenic } \\
\text { activities } \\
\text { d }\end{array}$} \\
\hline & PSEA & $\begin{array}{l}\text { East and } \\
\text { South Asia }\end{array}$ & PSEA & $\begin{array}{r}\text { East and } \\
\text { South Asia }\end{array}$ \\
\hline $\mathrm{CO}\left[\mathrm{Tg} \mathrm{yr}^{-1}\right]$ & 32 & 67 & 21 & 300 \\
\hline $\mathrm{BC}\left[\mathrm{TgC} \mathrm{yr}^{-1}\right]$ & 0.21 & 0.45 & 0.18 & 3.0 \\
\hline $\mathrm{NO}_{\mathrm{X}}\left[\mathrm{TgN} \mathrm{yr}^{-1}\right]$ & 0.33 & 0.85 & 0.58 & 11 \\
\hline NMVOC $\left[\mathrm{TgC}_{\mathrm{yr}}^{-1}\right]$ & 5.7 & 12 & 5.0 & 55 \\
\hline
\end{tabular}

from hydrophobic to hydrophilic of 1.15 days (Park et al., 2005). GEOS-Chem has been used extensively to study the long-range transport of pollutants from Asia and from other parts of the world (e.g, Liu et al., 2003; Park et al., 2005; Leung et al., 2007; Turquety et al., 2007; Zhang et al., 2008).

Table 1 summarizes the emissions used in our model simulations. Annual biomass-burning emission totals for East and South Asia (domain shown in Fig. 3, including East Asia, South Asia and Southeast Asia) were taken from the inventory developed by Streets et al. (2003a), which had a native resolution of $1^{\circ} \times 1^{\circ}$ and represented average burning conditions of the mid-1990s. Annual biomass-burning emissions of $\mathrm{CO}, \mathrm{NO}_{\mathrm{x}}$, non-methane volatile organic compounds (NMVOC), and BC from PSEA were $32 \mathrm{Tg} \mathrm{yr}^{-1}$, $0.33 \mathrm{TgN} \mathrm{yr}^{-1}$ (as $\mathrm{NO}_{2}$ ), 5.7 $\mathrm{Tg} \mathrm{yr}^{-1}$, and $0.21 \mathrm{TgC} \mathrm{yr}^{-1}$, respectively. Monthly variations of East and South Asia biomass-burning emissions were from Duncan et al. (2001). Over PSEA, $82 \%$ of the annual total biomass-burning emissions were emitted in the spring; half of the annual emission total was emitted in March. We applied daily variations to the emission fluxes by convoluting the monthly emission totals with the satellite-based daily burned area from the Global Fire Emissions Database version 4 (GFED4 - Giglio et al., 2013). Monthly mean biomass-burning emissions for the rest of the world were taken from the Global Fire Emissions Database version 2 (GFED2 - van der Werf et al., 2006) for the year 2001. The GFED2 inventory was not used for PSEA, because it has been shown to be significantly low-biased for the PSEA region (Fu et al., 2012).

Anthropogenic emissions for East and South Asia were taken from the inventory developed by Zhang et al. (2009), which had a native resolution of $0.5^{\circ} \times 0.5^{\circ}$ and included emissions from power generation, industry, transportation, as well as residential sources. This inventory was developed for the year 2006 but the emission totals were consistent with top-down emission estimates for $\mathrm{CO}$ (Heald et al., 2004) and NMVOC (Fu et al., 2007) for the year 2001. $\mathrm{BC}$ and $\mathrm{NO}_{\mathrm{x}}$ emission estimates were likely to be high relative to the actual emissions in the year 2001 (Zhang et al., 2009). For PSEA, the total annual anthropogenic emis- sions of $\mathrm{CO}, \mathrm{NO}_{\mathrm{x}}, \mathrm{NMVOC}$, and $\mathrm{BC}$ were $20.5 \mathrm{Tg} \mathrm{yr}^{-1}$, $0.59 \mathrm{TgN} \mathrm{yr}^{-1}$ (as $\mathrm{NO}_{2}$ ), 5.0 $\mathrm{Tg} \mathrm{yr}^{-1}$, and $0.18 \mathrm{TgC} \mathrm{yr}^{-1}$, respectively. The seasonal variations of emissions for the residential sector were dependent on monthly mean temperatures (Streets et al., 2003b). The monthly variations of powergeneration and industrial emissions for China were based on provincial monthly activity data (Zhang et al., 2009). For the rest of the world, we used annual mean anthropogenic emissions from the Emissions Database for Global Atmospheric Research (EDGAR) inventory for the year 2000 (Olivier and Berdowski, 2001) for $\mathrm{CO}$ and $\mathrm{NO}_{\mathrm{x}}$ and from the Reanalysis of the Tropospheric (RETRO) inventory for the year 2000 (Schultz et al., 2007) for NMVOCs. Biogenic VOC emissions were from the Model of Emissions of Gases and Aerosols from Nature (MEGAN) inventory version 2.1 (Guenther et al., 2012), with seasonal variations driven by leaf area index observations from MODIS (Myneni et al., 2002).

\subsection{Aircraft measurements from the TRACE-P campaign}

We compared our model results to aircraft measurements during the TRACE-P campaign in spring 2001 (Jacob et al., 2003). Two NASA aircraft were deployed during the campaign: the DC-8 (12 km ceiling) and the P-3B ( $7 \mathrm{~km}$ ceiling). BC absorption was measured on both aircraft at $565 \mathrm{~nm}$ using particle soot absorption photometers (Radiance Research) and corrected for scattering (Bond et al., 1999; Clarke et al., 2004). We calculated BC concentrations by assuming a mass absorption efficiency of $7.5 \mathrm{~m}^{2} \mathrm{~g}^{-1}$ (Bond et al., 2013) and converting to standard temperature and pressure conditions $(298 \mathrm{~K}$ and $1013 \mathrm{hPa}$, STP). On both aircraft, whole air samples were collected in canisters every 3-7 min during horizontal flight legs and every 1-3 min during ascents and descents. $\mathrm{CH}_{3} \mathrm{Cl}$ and $\mathrm{C}_{2} \mathrm{Cl}_{4}$ concentrations in these canister air samples were determined using gas chromatography (Blake et al., 2003). $\mathrm{BC}, \mathrm{CH}_{3} \mathrm{Cl}$, and $\mathrm{C}_{2} \mathrm{Cl}_{4}$ measurements were synchronized to a time resolution of one minute to identified the samples heavily impacted by biomass burning $\left(\mathrm{CH}_{3} \mathrm{Cl}>550 \mathrm{ppt}\right.$ and $\left.\mathrm{C}_{2} \mathrm{Cl}_{4}<3 \mathrm{ppt}\right)$ following Kondo et al. (2004). Measurements and model results were both averaged to the temporal $(15 \mathrm{~min})$ and spatial $\left(2.5^{\circ}\right.$ longitude $\times 2^{\circ}$ latitude) resolution of the model for comparison (Sect. 5).

\section{Injection height of springtime biomass-burning smoke plumes over PSEA}

\subsection{Probability distributions of smoke pixel heights}

We analyzed the MODIS and MISR observations over PSEA between February-April for the years 2001-2010 to identify the smoke plumes from biomass burning. MODIS detected 20000 thermal anomalies in MISR footprints over PSEA 

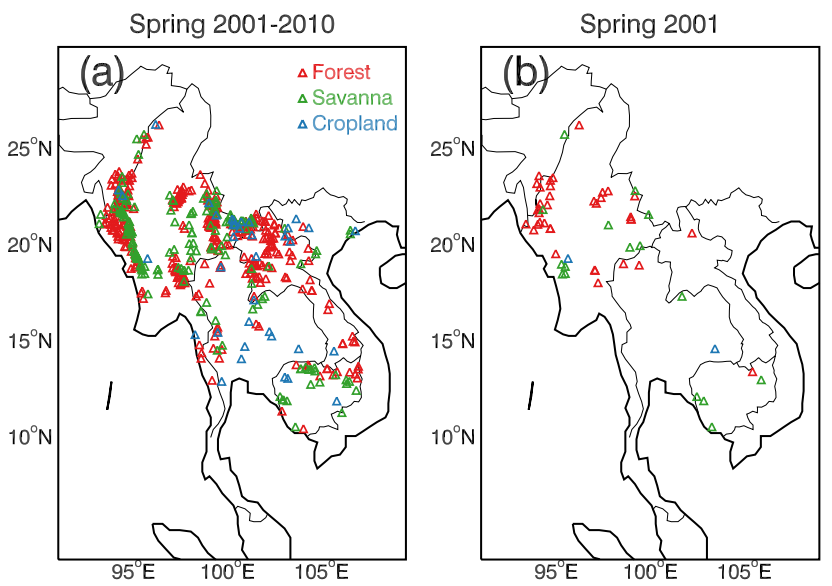

Fig. 1. Locations of identified smoke plumes over PSEA during February-April (a) for the years 2001 to 2010 and (b) for the year 2001. Symbols represent plumes over evergreen and deciduous broadleaf forests (red), woody savannas (green), and cropland and cropland/natural vegetation mosaics (blue).

during the target time periods. Using the criteria described in Sect. 2.2, a total of 607 biomass-burning smoke plumes were identified. Each identified smoke plume contained 10 to 400 smoke pixels. In all, heights were retrieved for 22350 smoke pixels during February-April for the years 2001-2010.

Figure 1 shows the spatial distributions of the identified biomass-burning smoke plumes during February-April for the years 2001 to 2010 and for the year 2001 alone. The identified smoke plumes were largely distributed over agricultural areas near major rivers, including the Mekong, the Chao Phraya, the Salween, and the Irrawaddy. The areas with highest densities of identified smoke plumes were northern Laos and western Myanmar. The MODIS thermal anomalies also showed a similar spatial distribution (not shown). There was no significant difference in the spatial distributions of the identified smoke plumes from year to year.

Figure 2 shows the probability distribution of all smoke pixel heights (binned into $0.5 \mathrm{~km}$ intervals) in the spring during the years 2001 to 2010 . Retrieved smoke pixel heights ranged from 0 to $6 \mathrm{~km}$ above the local terrain. Fifty-five percent of the smoke pixels were below $1 \mathrm{~km}$, which was the mean local boundary layer height at Terra overpass time (10:30 a.m. local time) in the MERRA data set. Approximately $28 \%$ of the smoke pixels were between $1 \mathrm{~km}$ and $2 \mathrm{~km}$, and $17 \%$ of the smoke pixels were above $2 \mathrm{~km}$. Only $1.5 \%$ of the smoke pixels were between 4 and $5 \mathrm{~km}$, and only $0.4 \%$ of the smoke pixels were between 5 and $6 \mathrm{~km}$. Overall, $45 \%$ of the smoke pixels were above the local mean boundary layer. Figure 2 also shows the range of smoke pixel height probability for each year between 2001 and 2010. There was considerable interannual variability in the probability distribution of the smoke pixel heights. The percentage of smoke pixels above $1 \mathrm{~km}$ was lowest at $24 \%$ in 2010 and highest at

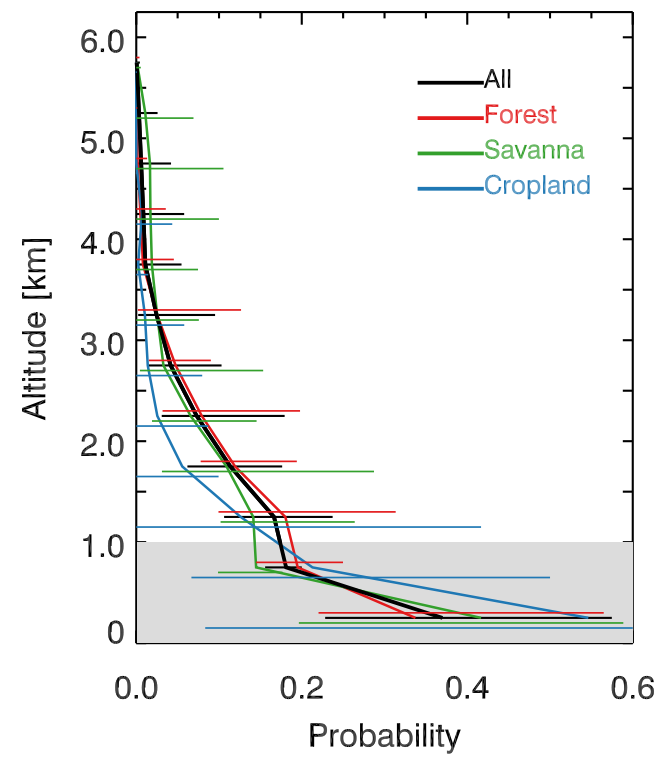

Fig. 2. Probability distribution of all smoke pixel heights from smoke plumes observed by MISR during February to April for the years 2001-2010 (black line). The grey area below $1 \mathrm{~km}$ altitude indicates the mean local boundary layer at Terra overpass time (10:30 local time) in the MERRA assimilated meteorology data set. Also shown are probability distributions for smoke pixel heights associated with different land covers: evergreen and deciduous broadleaf forest (red), woody savanna (green), and cropland and cropland/natural vegetation mosaic (blue). The error bars show the range of probability for individual years between 2001 and 2010 .

$58 \%$ in 2007 . The percentage of smoke pixels above $1 \mathrm{~km}$ was $57 \%$ in 2001.

We found that the smoke pixel heights varied with the type of land cover burned. Figure 1 shows the land cover at the locations of each of the identified smoke plumes. Out of the 607 smoke plumes identified during 2001-2010, $64 \%$ were over evergreen and deciduous broadleaf forests, $30 \%$ were over woody savanna, and $6 \%$ were over cropland or cropland/natural vegetation mosaic. This likely indicates extensive slashing and burning of forested areas for agriculture in the PSEA region. Alternatively, the smaller scale fires over croplands may be under-detected, and we will return to this point in Sect. 3.2. Figure 2 also shows the probability distributions of smoke pixel heights over broadleaf forests, woody savanna, and cropland. The retrieved heights of smoke pixels over croplands were significantly lower in altitude compared to those over broadleaf forests and savanna. We analyzed several cases of MODIS fire radiative power within the smoke plumes and found that the fires were less energetic over croplands than over forests and savanna. Seventysix percent of the smoke pixels over croplands were below $1 \mathrm{~km}$, with no pixels above $4 \mathrm{~km}$. Forty-four percent of the smoke pixels over woody savanna were above $1 \mathrm{~km}$, with $1.1 \%$ above $5 \mathrm{~km}$. Forty-seven percent of the smoke pixels 
over broadleaf forests were above $1 \mathrm{~km}$, with $0.1 \%$ above $5 \mathrm{~km}$.

\subsection{Uncertainty analysis}

The probability distributions of smoke pixel heights determined in Sect. 3.1 were susceptible to possible biases from sampling. The smoke plume heights detected at Terra satellite overpass time (approximately 10:30 a.m. local time) may not be representative of the smoke plumes during other times of the day, especially for fires associated with agriculture. Giglio (2007) showed that the diurnal cycle of fire activity over Southeast Asia peaks at 15:00 local time. Also, the MISR swath is $360 \mathrm{~km}$ wide while the MODIS swath is $2330 \mathrm{~km}$ wide. As a result, $85 \%$ of the fire pixels detected by MODIS were not within MISR footprints. In addition, fires and smoke plumes obscured by clouds were not detected by either MODIS or MISR. We assumed that the smoke plumes outside of the MISR temporal and spatial footprints or obscured by clouds had the same smoke pixel height distribution as the ones analyzed in Sect. 3.1. However, we acknowledge that these are important uncertainties that should be further investigated using complementary in situ or remote sensing measurements.

Additional uncertainty in the smoke pixel height probability distribution may come from the under-identification of small or low plumes. In our analysis, only half of the MODIS thermal anomalies within MISR footprints were associated with a visible smoke plume. Some of the thermal anomalies without visible smoke plumes may be false detection due to sun glint, hot desert surface, coasts, or clouds (Giglio et al., 2003). However, it was also possible that smoke plumes that were small or close to the surface were not visible to our eyes in the MISR imageries due to their low reflectivity contrast. To assess this bias, we analyzed the number of thermal anomalies associated with each of the identified smoke plumes in spring 2010. We found that each of the identified smoke plumes was associated with a range of 1 to 12 MODIS thermal anomalies at the vertex of the plume. The thermal anomalies not associated with visible smoke plumes were in most cases stand-alone. We assumed that these standalone thermal anomalies were detected falsely or associated with very small fires with little emission. To each cluster of more than two MODIS thermal anomalies but without a visible smoke plume, we assigned five smoke pixels (half the smallest number of smoke pixels in identified plumes), each with a height $<500 \mathrm{~m}$ (the lowest altitude bin in Fig. 2). A total of 105 smoke pixels were thus assigned. The resulting difference in the overall probability of smoke pixel height below $1 \mathrm{~km}$ was less than $3 \%$, and we ignored this source of error henceforth.

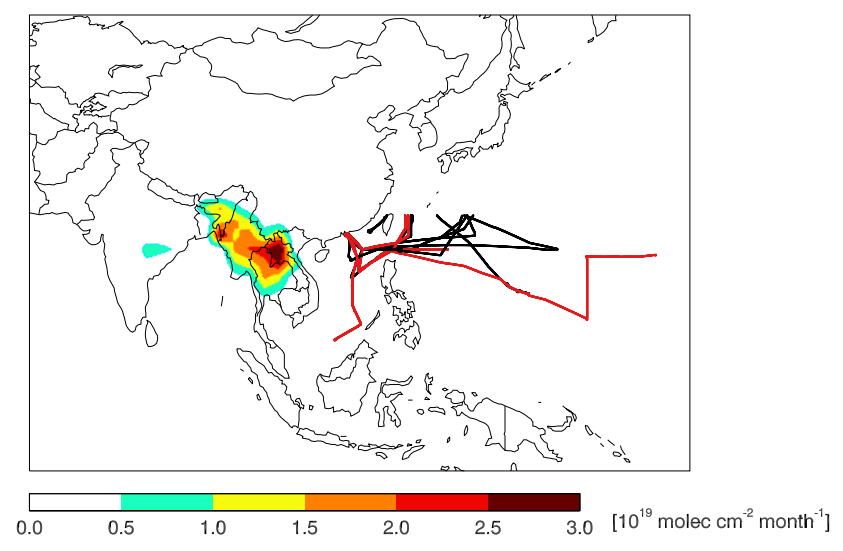

Fig. 3. Monthly mean biomass-burning emissions of CO from East and South Asia for March 2001. Monthly mean emission totals were from the inventory developed by Streets et al. (2003) and temporally distributed based on the daily burned area from GFED4 (Giglio et al., 2013). Also shown are the locations of the BC measurements over the northwestern Pacific from the Trace-P aircraft campaign which we used for model evaluation in Sect. 5 (black lines: DC-8; red lines: $\mathrm{P}-3 \mathrm{~B})$.

\section{Impacts of smoke injection height on long-range pollutant transport and ozone formation}

\subsection{Long-range transport of $\mathrm{CO}$}

We used the GEOS-Chem model to simulate the outflow of PSEA biomass-burning pollutants in spring 2001 and assessed the impacts of smoke plume injection heights on the long-range transport of pollutants. Two simulations were conducted. In the control simulation, all biomass-burning emissions were released evenly within the boundary layer following the standard practice in GEOS-Chem. In the sensitivity simulation, the biomass-burning emissions over PSEA were released according to the probability distribution of smoke pixel heights observed by MISR for the year 2001. That is, $40 \%$ of the PSEA biomass-burning emissions were released in the model evenly between the top of the local boundary layer and $5 \mathrm{~km}$ altitude, while the remaining $60 \%$ were released in the boundary layer. Both simulations were conducted from July 2000 to April 2001. The first eight months spun up the model. Below we focused on March 2001, when the biomass-burning emissions from PSEA were at their peak. Figure 3 shows the biomassburning emissions of CO for March 2001. Emissions were high over the entire PSEA with the largest fluxes exceeding $5 \times 10^{12}$ molecules $\mathrm{cm}^{-2} \mathrm{~s}^{-1}$ over northern Laos and western Myanmar, consistent with the locations of smoke plumes observed by MISR (Fig. 1).

Figure $4 \mathrm{a}$ and $\mathrm{b}$ show the monthly mean $\mathrm{CO}$ concentrations in March 2001 in the control simulation, as well as the fraction contributed by PSEA biomass burning and the monthly mean wind fields, at five different altitudes. At the 
surface, the highest $\mathrm{CO}$ concentrations exceeding $300 \mathrm{ppb}$ were found over PSEA, where the local biomass-burning emissions contributed $10-40 \%$ of the surface CO. PSEA biomass-burning emissions also contributed $5-15 \%$ of surface $\mathrm{CO}$ over Southwest China near the China-PSEA border, but otherwise had little impact on the surface CO concentrations over the rest of East Asia. At $850 \mathrm{hPa}$, the area most affected by PSEA biomass-burning emissions remained over PSEA, indicating that the emitted pollutants were largely transported vertically between the surface and $850 \mathrm{hPa}$ over PSEA in the control simulation. At $700 \mathrm{hPa}$ and above, however, the area most affected by PSEA biomass-burning emissions shifted northwestward to southern China and extended to the northwestern Pacific, reflecting the transport by the southwesterly to westerly wind at this altitude. Over southern China and the northwestern Pacific, PSEA biomass-burning contribution was most prominent at $700 \mathrm{hPa}$, consistent with previous ozonesonde and aircraft observations of the PSEA outflows (Liu et al., 1999; Chan et al., 2000; Carmichael et al., 2003).

Figure $4 \mathrm{c}$ shows the percent changes of the monthly mean $\mathrm{CO}$ concentrations in the MISR-constrained simulation relative to the control simulation. We found that directly injecting PSEA biomass-burning pollutants into the free troposphere had only a small impact on the long-range transport of CO. Over the PSEA source region, $\mathrm{CO}$ concentrations decreased by $3-10 \%$ at the surface and increased by $3-10 \%$ at $700 \mathrm{hPa}$, reflecting the direct injection of $\mathrm{CO}$ into the free troposphere in the MISR-constrained simulation. Downwind, CO concentrations increased by less than $5 \%$ at $700 \mathrm{hPa}$ over the South China sea, with no significant changes anywhere else. Figure 5a shows the percentage difference of the tropospheric column CO burden in the MISR-constrained simulation relative to the control simulation. The direct injection of PSEA smoke plumes into the free troposphere led to less than $1 \%$ decrease in the $\mathrm{CO}$ burden over the source and downwind regions.

Why was the long-range transport of biomass-burning $\mathrm{CO}$ from PSEA insensitive to the smoke plume injection height? We found that the surface circulation over PSEA in March was dominated by a persisting low-pressure system, which converged surface air and induced deep convection over the region (Fig. 4b). That deep convection was enhanced by the passage of cold fronts associated with midlatitude cyclones every 2-7 days (Liu et al., 2003). Therefore, CO, which has a lifetime of 1-2 months, was efficiently lifted by these synoptic-scale processes from the surface to $2-3 \mathrm{~km}$, where it was subsequently transported downwind by the persistent westerly. We concluded that for PSEA biomass-burning pollutants with lifetime significantly longer than 7 days (the synoptic timescale), their long-range transport was relatively insensitive to the plume injection heights on a monthly basis. This finding was similar to that of Chen et al. (2009) for North American boreal fire emissions.

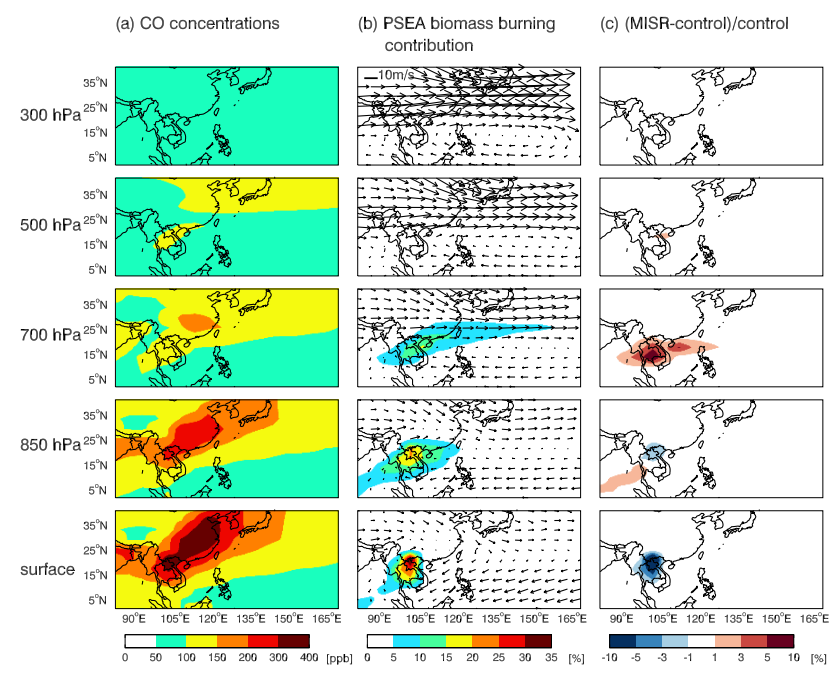

Fig. 4. (a) Monthly mean CO concentrations and (b) the fractions contributed by biomass burning from PSEA at five different altitudes during March 2001 in the control simulation. Arrows indicate the monthly mean wind. (c) The percent changes of simulated monthly mean CO concentrations in the MISR-constrained simulation relative to the control simulation.

\subsection{Impacts on the long-range transport of $\mathrm{BC}, \mathrm{NO}_{\mathrm{x}}$, and peroxyacetyl nitrate (PAN), and the formation of ozone}

Figure 6a shows the percent changes of $\mathrm{BC}$ concentrations in the MISR-constrained simulation relative to the control simulation during March 2001. We found that the long-range transport of $\mathrm{BC}$ was more sensitive to the smoke plume injection height than that of CO. Over PSEA, surface BC concentrations decreased by $20-40 \%$, reflecting the smaller amount of biomass-burning pollutants released at the surface in the MISR-constrained simulation. At $700 \mathrm{hPa}$, the increases in $\mathrm{BC}$ concentrations as a result of the direct injection of $\mathrm{BC}$ pollutants into the free troposphere were 50-100\%, much larger than those for CO. BC over PSEA was removed by wet scavenging at a timescale of four days. As a result, surface BC was not as efficiently transported into the free troposphere by deep convection, such that the impact of direct injection into the free troposphere was more pronounced. Subsequent eastward transport of BC to southern China and the northwestern Pacific between $15-25^{\circ} \mathrm{N}$ increased by as much as $70 \%$ at $700 \mathrm{hPa}$ and by $20-50 \%$ at $500 \mathrm{hPa}$. Interestingly, $\mathrm{BC}$ concentrations also increased significantly by over $50 \%$ at low altitudes (surface to $850 \mathrm{hPa}$ ) over the tropical northwestern Pacific $\left(5-15^{\circ} \mathrm{N}, 130-160^{\circ} \mathrm{E}\right)$, where the prevailing wind was easterly. We found that this was due to the increased transport of $\mathrm{BC}$ to the northwestern $\mathrm{Pa}$ cific $\left(15-25^{\circ} \mathrm{N}\right)$ between $700 \mathrm{hPa}$ and $500 \mathrm{hPa}$. Part of this $\mathrm{BC}$ was then transported clockwise by the Pacific subtropical high pressure system and carried to lower altitude by the subsiding northeasterly flow between $5-15^{\circ} \mathrm{N}$ (Fig. 6a). To 
(a) $\mathrm{CO}$

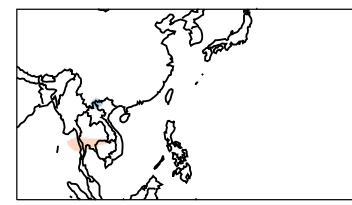

(b) $\mathrm{BC}$

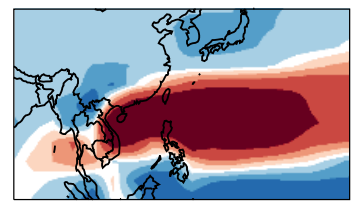

(c) $\mathrm{NO}_{x}$

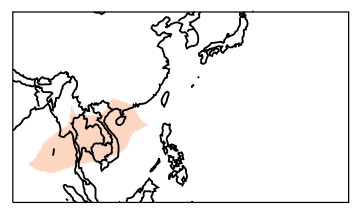

(d) PAN

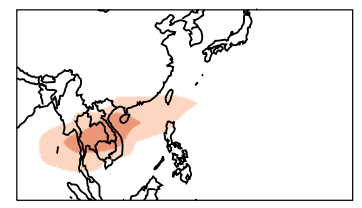

(e)

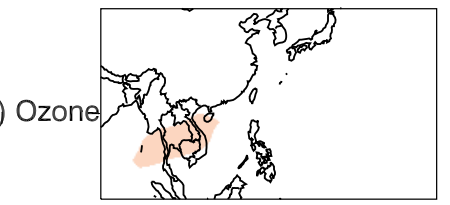

Fig. 5. Percent differences of tropospheric column (a) $\mathrm{CO}$, (b) BC, (c) $\mathrm{NO}_{\mathrm{x}}$, (d) peroxyacetyl nitrate (PAN), and (e) ozone concentrations in the MISR-constrained simulation relative to control simulation during March 2001.

the best of our knowledge, this transport pathway of PSEA pollutants to the tropical northwestern Pacific in the spring has not been reported previously. The BC thus transported may impact the marine boundary layer dynamics through its semi-direct radiative effect (Koch and Del Genio, 2010) and warrants further investigation.

Figure 6 also shows the percent changes of $\mathrm{NO}_{\mathrm{x}}$, PAN, and ozone concentrations in the MISR-constrained simulation relative to the control simulation. The photochemical lifetime of $\mathrm{NO}_{\mathrm{x}}$ in the lower troposphere is only several hours, shorter than the timescale of deep convection. Therefore, the vertical profile of $\mathrm{NO}_{\mathrm{x}}$ over the source region was also sensitive to the injection height of smoke plume. As seen in Fig. 6b, monthly mean $\mathrm{NO}_{\mathrm{x}}$ concentrations over PSEA decreased by $5-20 \%$ at the surface and increased by 10 $50 \%$ at $700 \mathrm{hPa}$. This change in $\mathrm{NO}_{\mathrm{x}}$ then drove changes in the formation of PAN (Fig. 6c), such that PAN concentrations increased by $10-40 \%$ at $700 \mathrm{hPa}$. The increases of $\mathrm{NO}_{\mathrm{x}}$ and PAN lead to increase in ozone over PSEA and the downwind region (Fig. 6d). During 1-5 March, when PSEA biomass burning was strongest, the daily mean $\mathrm{NO}_{\mathrm{x}}$, PAN and ozone concentrations could increase by as much as $40 \%$,

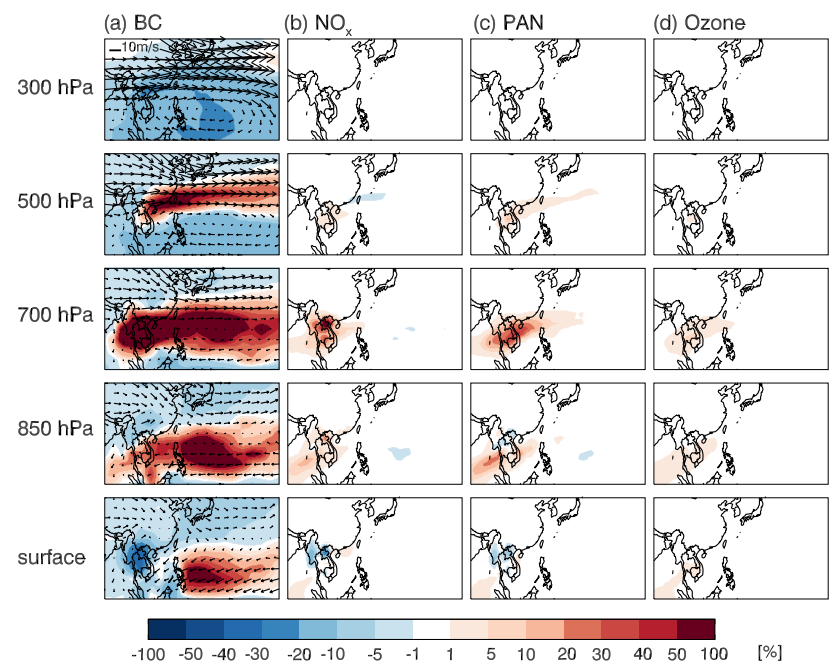

Fig. 6. Percent changes of pollutant concentrations in the MISRconstrained simulation relative to the control simulation for (a) BC, (b) $\mathrm{NO}_{\mathrm{x}}$, (c) PAN, and (d) ozone at five altitudes during March 2001. Arrows indicate the monthly mean wind.

$50 \%$ and $20 \%$, respectively, over the northwestern Pacific. On a monthly mean basis, however, the changes of $\mathrm{NO}_{\mathrm{x}}$, PAN and ozone concentrations over the northwestern Pacific were within $5 \%$, since the monthly mean contribution of the PSEA biomass-burning emissions to $\mathrm{NO}_{\mathrm{x}}$ there was less than $2 \%$.

Figure 5b-e shows the percent changes of the monthly mean column burden of $\mathrm{BC}, \mathrm{NO}_{\mathrm{x}}, \mathrm{PAN}$, and ozone in the MISR-constrained simulation relative to the control simulation. The tropospheric $\mathrm{BC}$ burden was most sensitive to the smoke plume injection height and increased by $20-30 \%$ between $5-25^{\circ} \mathrm{N}$ over the northwestern Pacific. The column burden of $\mathrm{NO}_{\mathrm{x}}, \mathrm{PAN}$, and ozone increased 1-10\% above PSEA.

\section{Comparison with TRACE-P aircraft measurements of $\mathrm{BC}$}

Our model simulations in Sect. 4 showed the injection height of smoke plumes over PSEA had the largest impact on the long-range transport of PSEA biomass-burning $\mathrm{BC}$ to the northwestern Pacific. Here we compared model results against TRACE-P aircraft measurements over the northwestern Pacific (south of $25^{\circ} \mathrm{N}$ ). Figure 3 shows the location of aircraft measurements used in our analysis. We sampled the model along the flight tracks at $1 \mathrm{~min}$ intervals. Measurements and model results were both averaged to the temporal (15 min) and spatial resolution of the model for comparison. Intercomparison flights during TRACE-P showed that the aerosol absorption measurements on the DC- 8 were systematically higher than that on the P-3B (Moore et al., 2004). We examined the data from the two aircraft separately. 
(a) DC-8 all

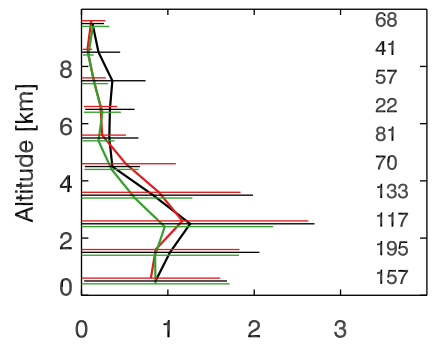

(c) DC-8 biomass burning

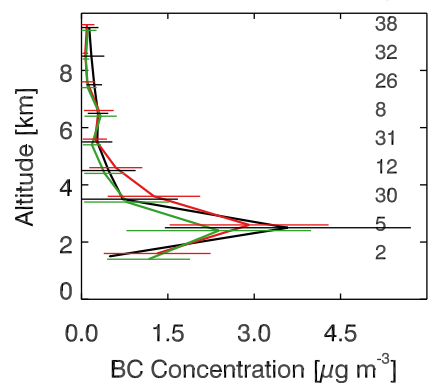

(b) P-3B all

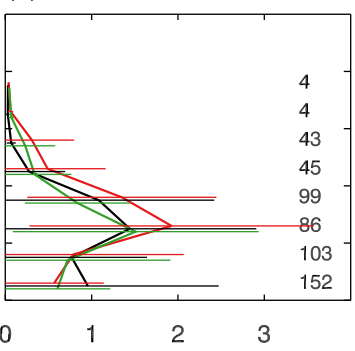

(d) P-3B biomass burning

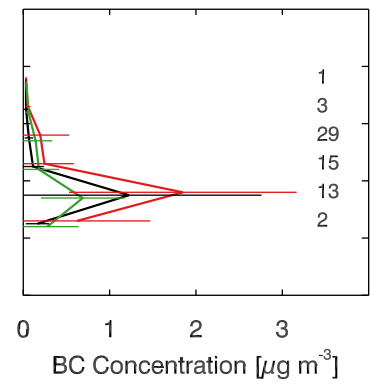

Fig. 7. Vertical profiles of $\mathrm{BC}$ concentrations over the northwestern Pacific (south of $25^{\circ} \mathrm{N}$ ) as measured by aircraft during the TRACE$\mathrm{P}$ campaign and as simulated by the model. The black, red and green lines represent $\mathrm{BC}$ concentrations from the aircraft observations, the sensitivity simulation using the MISR injection height profile, and the control simulation, respectively. Upper panel: all air masses sampled by the TRACE-P aircraft (DC-8 and P-3B). Lower panel: air masses significantly impacted by biomass burning. Model results were sampled along the flight tracks (Fig. 3). Measurements and model results were both averaged to the temporal and spatial resolution of the model for comparison. The error bars show the standard deviations. The numbers on the right are the numbers of model grids averaged.

Figure $7 \mathrm{a}$ and $\mathrm{b}$ compare the observed and simulated vertical profiles of $\mathrm{BC}$ concentrations in all air masses sampled by the aircraft. On both aircraft, measured BC con-

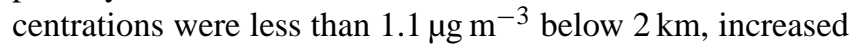
to $>1.4 \mu \mathrm{g} \mathrm{m}^{-3}$ around $3 \mathrm{~km}$, and decreased sharply to $<0.3 \mu \mathrm{g} \mathrm{m}^{-3}$ above $4 \mathrm{~km}$. The local maximum of BC concentrations at $2-3 \mathrm{~km}\left(1.4 \mu \mathrm{g} \mathrm{m}^{-3}\right.$ on the DC-8 and $1.7 \mu \mathrm{g} \mathrm{m}^{-3}$ on the $\mathrm{P}-3 \mathrm{~B}$ ) reflected the altitude of the outflow from PSEA, as shown previously in the back trajectory analysis by Kondo et al. (2004). Both the control simulation and the MISRconstrained simulation reproduced the general features of the observed vertical profiles. The outflow feature at $2-3 \mathrm{~km}$ was more pronounced in the MISR-constrained simulation, with simulated BC concentrations $21 \%$ (DC-8 track) and $27 \%$ (P-3B track) higher than those in the control simulation.

We further compared model results against the measured $\mathrm{BC}$ concentrations only in air masses significantly impacted by biomass-burning emissions (Figs. 7c, d), based on the criteria that measured $\mathrm{CH}_{3} \mathrm{Cl}>550$ ppt and $\mathrm{C}_{2} \mathrm{Cl}_{4}<3$ ppt following Kondo et al. (2004). There was no measurement be- low $2 \mathrm{~km}$ on both aircraft. Measured BC concentrations on both aircraft were highest at approximately $3 \mathrm{~km}\left(3.9 \mu \mathrm{g} \mathrm{m}^{-3}\right.$ on the DC- 8 and $1.2 \mu \mathrm{g} \mathrm{m}^{-3}$ on the P-3B) then decreased to $<0.2 \mu \mathrm{g} \mathrm{m}^{-3}$ above $4 \mathrm{~km}$. Both the control simulation and the MISR-constrained simulation reproduced the shape of the observed BC vertical profiles. Again, the outflow feature at approximately $3 \mathrm{~km}$ was more pronounced in the MISRconstrained simulation, with simulated BC concentrations $22 \%$ (DC-8) and $168 \%$ (P3-B) higher than those in the control simulation.

Our analysis above showed that directly injecting $40 \%$ of the PSEA biomass-burning pollutants in the free troposphere in the model led to a more pronounced BC outflow at $3 \mathrm{~km}$ over the northwestern Pacific. This resulted in a slightly improved simulation of the DC- 8 observations and a slight overestimation of the P-3B observations, although the differences were within the observed variances. We emphasize that such comparison is neither sufficient proof nor disproof for the smoke plume injection height presented in Sect. 3. Many other factors may contribute to the model performance when comparing to the aircraft observations, such as the large uncertainties in the PSEA biomass-burning emissions and the $\mathrm{BC}$ wet scavenging rate. Our analysis highlighted the point that the injection heights of smoke plumes presents great uncertainty over the interpretation of BC measurements downwind of biomass-burning regions. In particular, discrepancies between model and measurements cannot be attributed solely to errors in the biomass-burning emission inventory, unless the impacts of plume injection heights have been addressed.

\section{Conclusions}

We analyzed satellite observations to determine the injection heights of biomass-burning smoke plumes over PSEA in the spring, with the goal of assessing the impacts of smoke injection heights on long-range pollutant transport. We retrieved the heights of 22350 smoke pixels during February to April of the years 2001 to 2010 . On average, $45 \%$ of the smoke pixels were above the mean local boundary layer top $(1 \mathrm{~km})$ at satellite overpass time.

We simulated the long-range transport of biomass-burning pollutants from PSEA using the GEOS-Chem model. We conducted a control simulation where all PSEA biomassburning emissions were released in the boundary layer, as well as a sensitivity simulation where $40 \%$ of the PSEA biomass-burning emissions were injected into the free troposphere. We found that the surface air over PSEA in March was well ventilated by deep convective activities triggered by synoptic-scale weather systems, such that the long-range transport of pollutants with lifetimes significantly longer than seven days (e.g., CO) was relatively insensitive to the smoke plume injection heights.

The long-range transport of shorter-lived pollutants was much more sensitive to the smoke plume injection height. 
The eastward transport of $\mathrm{BC}$ to southern China and the northwestern Pacific increased by $20-70 \%$ at $700 \mathrm{hPa}$. BC concentrations also increased significantly at low altitudes over the tropical northwestern Pacific, due to transport by the Pacific subtropical high pressure system. The direct injection of PSEA biomass-burning $\mathrm{NO}_{\mathrm{x}}$ into the free troposphere drove increased formation and transport of PAN, which in turn led to a small increase in ozone over downwind regions.

We compared our model results to aircraft measurements over the northwestern Pacific during the TRACE-P campaign (March 2001). The direct injection of $40 \%$ of the PSEA biomass-burning pollutants in the free troposphere in the model led to a more pronounced BC peak at $3 \mathrm{~km}$ over the tropical northwestern Pacific, consistent with the outflow feature observed by the aircraft.

Our results showed that the smoke plume injection heights presents great uncertainty over the interpretation of shortlived species measurements downwind of biomass-burning regions. Discrepancies between model and measurements cannot be attributed solely to errors in the biomass-burning emission estimates, unless the impacts of plume injection heights have been addressed.

Acknowledgements. This work was funded by the National Natural Science Foundation of China $(41222035,41175101)$ and by the Ministry of Science and Technology of China (2014CB441303).

Edited by: I. Aben

\section{References}

Amiridis, V., Giannakaki, E., Balis, D. S., Gerasopoulos, E., Pytharoulis, I., Zanis, P., Kazadzis, S., Melas, D., and Zerefos, C.: Smoke injection heights from agricultural burning in Eastern Europe as seen by CALIPSO, Atmos. Chem. Phys., 10, 1156711576, doi:10.5194/acp-10-11567-2010, 2010.

Bey, I., Jacob, D. J., Yantosca, R. M., Logan, J. A., Field, B. D., Fiore, A. M., Li, Q. B., Liu, H. G. Y., Mickley, L. J., and Schultz, M. G.: Global modeling of tropospheric chemistry with assimilated meteorology: Model description and evaluation, J. Geophys. Res., 106, 23073-23095, doi:10.1029/2001JD000807, 2001.

Blake, N. J., Blake, D. R., Simpson, I. J., Meinardi, S., Swanson, A. L., Lopez, J. P., Katzenstein, A. S., Barletta, B., Shirai, T., Atlas, E., Sachse, G., Avery, M., Vay, S., Fuelberg, H. E., Kiley, C. M., Kita, K., and Rowland, F. S.: NMHCs and halocarbons in Asian continental outflow during the Transport and Chemical Evolution over the Pacific (TRACE-P) Field Campaign: Comparison With PEM-West B, J. Geophys. Res., 108, 8806, doi:10.1029/2002JD003367, 2003.

Bond, T. C., Anderson, T. L., and Campbell, D.: Calibration and intercomparison of filter-based measurements of visible light absorption by aerosols, Aerosol Sci. Tech., 30, 582-600, doi:10.1080/027868299304435, 1999.

Bond, T. C., Doherty, S. J., Fahey, D. W., Forster, P. M., Berntsen, T., DeAngelo, B. J., Flanner, M. G., Ghan, S., Kärcher, B.,
Koch, D., Kinne, S., Kondo, Y., Quinn, P. K., Sarofim, M. C., Schultz, M. G., Venkataraman, C., Zhang, H., Zhang, S., Bellouin, N., Guttikunda, S. K., Hopke, P. K., Jacobson, M. Z., Kaiser, J. W., Klimont, Z., Lohmann, U., Schwarz, J. P., Shindell, D., Storelvmo, T., Warren, S. G., and Zender, C. S.: Bounding the role of black carbon in the climate system: a scientific assessment, J. Geophys. Res., 118, 5380-5552, doi:10.1002/jgrd.50171, 2013.

Carmichael, G. R., Tang, Y., Kurata, G., Uno, I., Streets, D., Woo, J. H., Huang, H., Yienger, J., Lefer, B., Shetter, R., Blake, D., Atlas, E., Fried, A., Apel, E., Eisele, F., Cantrell, C., Avery, M., Barrick, J., Sachse, G., Brune, W., Sandholm, S., Kondo, Y., Singh, H., Talbot, R., Bandy, A., Thorton, D., Clarke, A., and Heikes, B.: Regional-scale chemical transport modeling in support of the analysis of observations obtained during the TRACE-P experiment, J. Geophys. Res., 108, 8823, doi:10.1029/2002JD003117, 2003.

Chan, L. Y., Chan, C. Y., Liu, H. Y., Christopher, S., Oltmans, S. J., and Harris, J. M.: A case study on the biomass burning in southeast Asia and enhancement of tropospheric ozone over Hong Kong, Geophys. Res. Lett., 27, 1479-1482, doi:10.1029/1999GL010855, 2000.

Chen, Y., Li, Q., Randerson, J. T., Lyons, E. A., Kahn, R. A., Nelson, D. L., and Diner, D. J.: The sensitivity of CO and aerosol transport to the temporal and vertical distribution of North American boreal fire emissions, Atmos. Chem. Phys., 9, 6559-6580, doi:10.5194/acp-9-6559-2009, 2009.

Clarke, A. D., Shinozuka, Y., Kapustin, V. N., Howell, S., Huebert, B., Doherty, S., Anderson, T., Covert, D., Anderson, J., Hua, X., Moore, K. G., McNaughton, C., Carmichael, G., and Weber, R.: Size distributions and mixtures of dust and black carbon aerosol in Asian outflow: physiochemistry and optical properties, J. Geophys. Res., 119, D15S09, doi:10.1029/2003JD004378, 2004.

Colarco, P., Schoeberl, M., Doddridge, B., Marufu, L., Torres, O., and Welton, E.: Transport of smoke from Canadian forest fires to the surface near Washington, D.C.: Injection height, entrainment, and optical properties, J. Geophys. Res., 109, D06203, doi:10.1029/2003jd004248, 2004.

Damoah, R., Spichtinger, N., Servranckx, R., Fromm, M., Eloranta, E. W., Razenkov, I. A., James, P., Shulski, M., Forster, C., and Stohl, A.: A case study of pyro-convection using transport model and remote sensing data, Atmos. Chem. Phys., 6, 173185, doi:10.5194/acp-6-173-2006, 2006.

Deng, X., Tie, X., Zhou, X., Wo, D., Zhong, L., Tan, H., Li, F., Huang, X., Bi, X., and Deng, T.: Effects of Southeast Asia biomass burning on aerosols and ozone concentrations over the Pearl River Delta (PRD) region, Atmos. Environ., 42, 84938501, doi:10.1016/j.atmosenv.2008.08.013, 2008.

Diner, D. J., Beckert, J. C., Reilly, T. H., Bruegge, C. J., Conel, J. E., Kahn, R. A., Martonchik, J. V., Ackerman, T. P., Davies, R., Gerstl, S. A. W., Gordon, H. R., Muller, J. P., Myneni, R. B., Sellers, P. J., Pinty, B., and Verstraete, M. M.: Multi-angle Imaging SpectroRadiometer (MISR) instrument description and experiment overview, IEEE T. Geosci. Remote, 36, 1072-1087, doi:10.1109/36.700992, 1998.

Duncan, B. N., Martin, R. V., Staudt, A. C, Yevich, R., and Logan, J. A.: Interannual and seasonal variability of biomass burning emissions constrained by satellite observations, J. Geophys. Res., 108, 4100, doi:1029/2002JD002378, 2001. 
Ferguson, S. A., Collins, R. L., Ruthford, J., and Fukuda, M.: Vertical distribution of nighttime smoke following a wildland biomass fire in boreal Alaska, J. Geophys. Res., 108, 4743, doi:10.1029/2002JD003324, 2003.

Fox, J., Fujita, Y., Ngidang, D., Peluso, N., Potter, L., Sakuntaladewi, N., Sturgeon, J., and Thomas, D.: Policies, PoliticalEconomy, and Swidden in Southeast Asia, Hum. Ecol., 37, 305322, doi:10.1007/s10745-009-9240-7, 2009.

Freitas, S. R., Longo, K. M., and Andreae, M. O.: Impact of including the plume rise of vegetation fires in numerical simulations of associated atmospheric pollutants, Geophys. Res. Lett., 33, L17808, doi:10.1029/2006GL026608, 2006.

Freitas, S. R., Longo, K. M., Chatfield, R., Latham, D., Silva Dias, M. A. F., Andreae, M. O., Prins, E., Santos, J. C., Gielow, R., and Carvalho Jr., J. A.: Including the sub-grid scale plume rise of vegetation fires in low resolution atmospheric transport models, Atmos. Chem. Phys., 7, 3385-3398, doi:10.5194/acp-7-3385-2007, 2007.

Friedl, M. A., Sulla-Menashe, D., Tan, B., Schneider, A., Ramankutty, N., Sibley, A., and Huang, X.: MODIS Collection 5 global land cover: Algorithm refinements and characterization of new datasets, Remote Sens. Environ., 114, 168-182, doi:10.1016/j.rse.2009.08.016, 2010.

Fromm, M., Bevilacqua, R., Servranckx, R., Rosen, J., Thayer, J. P., Herman, J., and Larko, D.: Pyro-cumulonimbus injection of smoke to the stratosphere: Observations and impact of a super blowup in northwestern Canada on 3-4 August 1998, J. Geophys. Res., 110, D08205, doi:10.1029/2004JD005350, 2005.

Fu, T.-M., Jacob, D. J., Palmer, P. I., Chance, K., Wang, Y. X., Barletta, B., Blake, D. R., Stanton, J. C., and Pilling, M. J.: Space-based formaldehyde measurements as constraints on volatile organic compound emissions in east and south Asia and implications for ozone, J. Geophys. Res., 112, D06312, doi:10.1029/2006JD007853, 2007.

Fu, J. S., Hsu, N. C., Gao, Y., Huang, K., Li, C., Lin, N.-H., and Tsay, S.-C.: Evaluating the influences of biomass burning during 2006 BASE-ASIA: a regional chemical transport modeling, Atmos. Chem. Phys., 12, 3837-3855, doi:10.5194/acp-12-38372012, 2012.

Giglio, L.: Characterization of the tropical diurnal fire cycle using VIRS and MODIS observations, Remote Sens. Environ., 108, 407-421, doi:10.1016/j.rse.2006.11.018, 2007.

Giglio, L., Descloitres, J., Justice, C. O., and Kaufman, Y. J.: An enhanced contextual fire detection algorithm for MODIS, Remote Sens. Environ., 87, 273-282, doi:10.1016/S00344257(03)00184-6, 2003.

Giglio, L., Randerson, J. T., and van der Werf, G. R.: Analysis of daily, monthly, and annual burned area using the fourthgeneration global fire emissions database (GFED4), J. Geophys. Res., 118, 317-328, doi:10.1002/jgrg.20042, 2013.

Guenther, A. B., Jiang, X., Heald, C. L., Sakulyanontvittaya, T., Duhl, T., Emmons, L. K., and Wang, X.: The Model of Emissions of Gases and Aerosols from Nature version 2.1 (MEGAN2.1): an extended and updated framework for modeling biogenic emissions, Geosci. Model Dev., 5, 1471-1492, doi:10.5194/gmd-51471-2012, 2012.

Heald, C. L., Jacob, D. J., Jones, D. B., Palmer, P. I., Logan, J. A., Streets, D., Sachse, G. W., Gille, J. C., Hoffman, R. N., and Nehrkorn, T.: Comparative inverse analysis of satellite (MO-
PITT) and aircraft (TRACE-P) observations to estimate Asian sources of carbon monoxide, J. Geophys. Res., 109, D23306, doi:10.1029/2004JD005185, 2004.

Jacob, D. J., Crawford, J. H., Kleb, M. M., Connors, V. S., Bendura, R. J., Raper, J. L., Sachse, G. W., Gille, J. C., Emmons, L., and Heald, C. L.: Transport and Chemical Evolution over the Pacific (TRACE-P) aircraft mission: Design, execution, and first results, J. Geophys. Res., 108, 9000, doi:10.1029/2002jd003276, 2003.

Kahn, R. A., Li, W.-H., Moroney, C., Diner, D. J., Martonchik, J. V., and Fishbein, E.: Aerosol source plume physical characteristics from space-based multiangle imaging, J. Geophys. Res., 112, D11205, doi:10.1029/2006JD007647, 2007.

Kahn, R. A., Chen, Y., Nelson, D. L., Leung, F. Y., Li, Q. B., Diner, D. J., and Logan, J. A.: Wildfire smoke injection heights: two perspectives from space, Geophys. Res. Lett., 35, L04809, doi:10.1029/2007GL032165, 2008.

Koch, D. and Del Genio, A. D.: Black carbon semi-direct effects on cloud cover: review and synthesis, Atmos. Chem. Phys., 10, 7685-7696, doi:10.5194/acp-10-7685-2010, 2010.

Kondo, Y., Morino, Y., Takegawa, N., Koike, M., Kita, K., Miyazaki, Y., Sachse, G. W., Vay, S. A., Avery, M. A., Flocke, F., Weinheimer, A. J., Eisele, F. L., Zondlo, M. A., Weber, R. J., Singh, H. B., Chen, G., Crawford, J., Blake, D. R., Fuelberg, H. E., Clarke, A. D., Talbot, R. W., Sandholm, S. T., Browell, E. V., Streets, D. G., and Liley, B.: Impacts of biomass burning in Southeast Asia on ozone and reactive nitrogen over the western Pacific in spring, J. Geophys. Res., 109, D15S12, doi:10.1029/2003JD004203, 2004.

Labonne, M., Breon, F. M., and Chevallier, F.: Injection height of biomass burning aerosols as seen from a spaceborne lidar, Geophys. Res. Lett., 34, L11806, doi:10.1029/2007GL029311, 2007.

Leung, F.-Y. T., Logan, J. A., Park, R., Hyer, E., Kasischke, E., Streets, D., and Yurganov, L.: Impacts of enhanced biomass burning in the boreal forests in 1998 on tropospheric chemistry and the sensitivity of model results to the injection height of emissions, J. Geophys. Res., 112, D10313, doi:10.1029/2006JD008132, 2007.

Lin, C.-Y., Hsu, H.-M., Lee, Y. H., Kuo, C. H., Sheng, Y.-F., and Chu, D. A.: A new transport mechanism of biomass burning from Indochina as identified by modeling studies, Atmos. Chem. Phys., 9, 7901-7911, doi:10.5194/acp-9-7901-2009, 2009.

Lin, C.-Y., Chang, C.-C., Chan, C. Y., Kuo, C. H., Chen, W.-C., Chu, D. A., and Liu, S. C.: Characteristics of springtime profiles and sources of ozone in the low troposphere over northern Taiwan, Atmos. Environ., 44, 182-193, doi:10.1016/j.atmosenv.2009.10.020, 2010.

Lin, J.-T. and McElroy, M. B.: Impacts of boundary layer mixing on pollutant vertical profiles in the lower troposphere: implications to satellite remote sensing, Atmos. Environ., 44, 17261739, doi:10.1016/j.atmosenv.2010.02.009, 2010.

Liu, H., Chang, W. L., Oltmans, S. J., Chan, L. Y., and Harris, J. M.: On springtime high ozone events in the lower troposphere from Southeast Asian biomass burning, Atmos. Environ., 33, 24032410, doi:10.1016/S1352-2310(98)00357-4, 1999.

Liu, H. Y., Jacob, D. J., Bey, I., and Yantosca, R. M.: Constraints from $\mathrm{Pb}-210$ and $\mathrm{Be}-7$ on wet deposition and transport in a global three-dimensional chemical tracer model driven by assimilated meteorological fields, J. Geophys. Res., 106, 1210912128, 2001. 
Liu, H. Y., Jacob, D. J., Bey, I., Yantosca, R. M., Duncan, B. N., and Sachse, G. W.: Transport pathways for Asian pollution outflow over the Pacific: Interannual and seasonal variations, J. Geophys. Res., 108, 8786, doi:10.1029/2002JD003102, 2003.

Mao, J., Jacob, D. J., Evans, M. J., Olson, J. R., Ren, X., Brune, W. H., Clair, J. M. St., Crounse, J. D., Spencer, K. M., Beaver, M. R., Wennberg, P. O., Cubison, M. J., Jimenez, J. L., Fried, A., Weibring, P., Walega, J. G., Hall, S. R., Weinheimer, A. J., Cohen, R. C., Chen, G., Crawford, J. H., McNaughton, C., Clarke, A. D., Jaeglé, L., Fisher, J. A., Yantosca, R. M., Le Sager, P., and Carouge, C.: Chemistry of hydrogen oxide radicals $\left(\mathrm{HO}_{\mathrm{X}}\right)$ in the Arctic troposphere in spring, Atmos. Chem. Phys., 10, 58235838, doi:10.5194/acp-10-5823-2010, 2010.

Mazzoni, D., Logan, J. A., Diner, D., Kahn, R., Tong, L. L., and Li, Q. B.: A data-mining approach to associating MISR smoke plume heights with MODIS fire measurements, Remote Sens. Environ., 107, 138-148, doi:10.1016/j.rse.2006.08.014, 2007.

Mims, S. R., Kahn, R. A., Moroney, C. M., Gaitley, B. J., Nelson, D. L., and Garay, M. J.: MISR Stereo heights of grassland fire smoke plumes in Australia, IEEE T. Geosci. Remote, 48, 25-35, doi:10.1109/TGRS.2009.2027114, 2010.

Miyazaki, Y., Kondo, Y., Koike, M., Fuelberg, H. E., Kiley, C. M., Kita, K., Takegawa, N., Sachse, G. W., Flocke, F., Weinheimer, A. J., Singh, H. B., Eisele, F. L., Zondlo, M., Talbot, R. W., Sandholm, S. T., Avery, M. A., and Blake, D. R.: Synoptic-scale transport of reactive nitrogen over the western Pacific in spring, J. Geophys. Res., 108, 8788, doi:10.1029/2002JD003248, 2003.

Moore, K. G., Clarke, A. D., Kapustin, V. N., McNaughton, C., Anderson, B. E., Winstead, E. L., Weber, R., Ma, Y., Lee, Y. N., Talbot, R., Dibb, J., Anderson, T., Doherty, S., Covert, D., and Rogers, D.: A comparison of similar aerosol measurements made on the NASA P3-B, DC-8, and NSFC-130 aircraft during TRACE-P and ACE-Asia, J. Geophys. Res., 109, D15S15, doi:10.1029/2003jd003543, 2004.

Moroney, C., Davies, R., and Muller, J. P.: Operational retrieval of cloud-top heights using MISR data, IEEE T. Geosci. Remote, 40, 1532-1540, doi:10.1109/TGRS.2002.801150, 2002.

Myneni, R. B., Hoffman, S., Knyazikhin, Y., Privette, J. L., Glassy, J., Tian, Y., Wang, Y., Song, X., Zhang, Y., Smith, G. R., Lotsch, A., Friedl, M., Morisette, J. T., Votava, P., Nemani, R. R., and Running, S. W.: Global products of vegetation leaf area and fraction absorbed PAR from year one of MODIS data, Remote Sens. Environ., 83, 214-231, doi:10.1016/s00344257(02)00074-3, 2002.

Nelson, D. L., Chen, Y., Kahn, R. A., Diner, D. J., and Mazzoni, D.: Example applications of the MISR INteractive eXplorer (MINX) software tool to wild?re smoke plume analyses, in: SPIE 7089 Remote Sensing of Fire: Science and Application, San Diego, USA, 27 August 2008, 708909, 2008.

Nelson, D. L., Garay, M. J., Kahn, R. A., and Dunst, B. A.: Stereoscopic height and wind retrievals for aerosol plumes with the MISR INteractive eXplorer (MINX), Remote Sens., 5, 45934628, doi:10.3390/rs5094593, 2013.

Olivier, J. G. J. and Berdowski, J. J. M.: Global emissions sources and sinks, in: The Climate System, edited by: Berdowski, J., Guicherit, R., and Heij, B. J., A. A. Balkema Publishers/Swets \& Zeitlinger Publishers, Lisse, the Netherlands, 33-78, 2001.

Park, R. J., Jacob, D. J., Palmer, P. I., Clarke, A. D., Weber, R. J., Zondlo, M. A., Eisele, F. L., Bandy, A. R., Thornton, D. C.,
Sachse, G. W., and Bond, T. C.: Export efficiency of black carbon aerosol in continental outflow: Global implications, J. Geophys. Res., 110, D11205, doi:10.1029/2004JD005432, 2005.

Rio, C., Hourdin, F., and Chédin, A.: Numerical simulation of tropospheric injection of biomass burning products by pyro-thermal plumes, Atmos. Chem. Phys., 10, 3463-3478, doi:10.5194/acp10-3463-2010, 2010.

Schultz, M., Backman, L., Balkanski, Y., Bjoerndalsaeter, S., Brand, R., Burrows, J., Dalsoeren, S., de Vasconcelos, M., Grodtmann, B., Hauglustaine, D., Heil, A., Hoelzemann, J., Isaksen, I., Kaurola, J., Knorr, W., Ladstaetter-Weienmayer, A., Mota, B., Oom, D., Pacyna, J., Panasiuk, D., Pereira, J., Pulles, T., Pyle, J., Rast, S., Richter, A., Savage, N., Schnadt, C., Schulz, M., Spessa, A., Staehelin, J., Sundet, J., Szopa, S., Thonicke, K., van het Bolscher, M., van Noije, T., van Velthoven, P., Vik, A., and Wittrock, F.: REanalysis of the TROpospheric chemical composition over the past 40 years (RETRO) - A long-term global modeling study of tropospheric chemistry, Report No. 48/2007, Reports on Earth System Science, Max Planck Institute for Meteorology, Julich/Hamburg, Germany, 2007.

Streets, D. G., Yarber, K. F., Woo, J. H., and Carmichael, G. R.: Biomass burning in Asia: Annual and seasonal estimates and atmospheric emissions, Global Biogeochem. Cy., 17, 1099, doi:10.1029/2003gb002040, 2003a.

Streets, D. G., Bond, T. C., Carmichael, G. R., Fernandes, S. D., Fu, Q., He, D., Klimont, Z., Nelson, S. M., Tsai, N. Y., Wang, M. Q., Woo, J.-H., and Yarber, K. F.: An inventory of gaseous and primary aerosol emissions in Asia in the year 2000, J. Geophys. Res., 108, 8809, doi:10.1029/2002JD003093, 2003b.

Tosca, M. G., Randerson, J. T., Zender, C. S., Nelson, D. L., Diner, D. J., and Logan, J. A.: Dynamics of fire plumes and smoke clouds associated with peat and deforestation fires in Indonesia, J. Geophys. Res., 116, D08207, doi:10.1029/2010JD015148, 2011.

Turquety, S., Logan, J. A., Jacob, D. J., Hudman, R. C., Leung, F. Y., Heald, C. L., Yantosca, R. M., Wu, S. L., Emmons, L. K., Edwards, D. P., and Sachse, G. W.: Inventory of boreal fire emissions for North America in 2004: Importance of peat burning and pyroconvective injection, J. Geophys. Res., 112, 1-13, doi:10.1029/2006JD007281, 2007.

Val Martin, M., Logan, J. A., Kahn, R. A., Leung, F.-Y., Nelson, D. L., and Diner, D. J.: Smoke injection heights from fires in North America: analysis of 5 years of satellite observations, Atmos. Chem. Phys., 10, 1491-1510, doi:10.5194/acp-10-14912010, 2010.

Val Martin, M., Kahn, R. A., Logan, J. A., Paugam, R., Wooster, M., and Ichoku, C.: Space-based observational constraints for 1D fire smoke plume-rise models, J. Geophys. Res., 117, D22204, doi:10.1029/2012jd018370, 2012.

van der Werf, G. R., Randerson, J. T., Giglio, L., Collatz, G. J., Kasibhatla, P. S., and Arellano Jr., A. F.: Interannual variability in global biomass burning emissions from 1997 to 2004, Atmos. Chem. Phys., 6, 3423-3441, doi:10.5194/acp-6-3423-2006, 2006.

Wang, Y. H., Jacob, D. J., and Logan, J. A.: Global simulation of tropospheric $\mathrm{O}-3-\mathrm{NO}_{\mathrm{x}}$-hydrocarbon chemistry 1. Model formulation, J. Geophys. Res., 103, 10713-10725, doi:10.1029/98JD00158, 1998. 
Wesely, M. L.: Parameterization of surface resistances to gaseous dry deposition in regional-scale numerical models, Atmos. Environ., 23, 1293-1304, doi:10.1016/0004-6981(89)90153-4, 1989.

Wu, S, Mickley, L. J., Jacob, D. J., Logan, J. A., and Yantosca, R. M.: Why are there large differences between models in global budgets of tropospheric ozone?, J. Geophys. Res, 112, D05302, doi:10.1029/2006JD007801, 2007.

Yen, M.-C., Peng, C.-M., Chen, T.-C., Chen, C.-S., Lin, N.-H., Tzeng, R.-Y., Lee, Y.-A., and Lin, C.-C.: Climate and weather characteristics in association with the active fires in northern Southeast Asia and spring air pollution in Taiwan during 2010 7-SEAS/Dongsha Experiment, Atmos. Environ., 78, 3550, doi:10.1016/j.atmosenv.2012.11.015, 2012.

Zender, C. S., Krolewski, A. G., Tosca, M. G., and Randerson, J. T.: Tropical biomass burning smoke plume size, shape, reflectance, and age based on 2001-2009 MISR imagery of Borneo, Atmos. Chem. Phys., 12, 3437-3454, doi:10.5194/acp-123437-2012, 2012.
Zhang, L., Jacob, D. J., Boersma, K. F., Jaffe, D. A., Olson, J. R., Bowman, K. W., Worden, J. R., Thompson, A. M., Avery, M. A., Cohen, R. C., Dibb, J. E., Flock, F. M., Fuelberg, H. E., Huey, L. G., McMillan, W. W., Singh, H. B., and Weinheimer, A. J.: Transpacific transport of ozone pollution and the effect of recent Asian emission increases on air quality in North America: an integrated analysis using satellite, aircraft, ozonesonde, and surface observations, Atmos. Chem. Phys., 8, 6117-6136, doi:10.5194/acp-8-6117-2008, 2008.

Zhang, Q., Streets, D. G., Carmichael, G. R., He, K. B., Huo, H., Kannari, A., Klimont, Z., Park, I. S., Reddy, S., Fu, J. S., Chen, D., Duan, L., Lei, Y., Wang, L. T., and Yao, Z. L.: Asian emissions in 2006 for the NASA INTEX-B mission, Atmos. Chem. Phys., 9, 5131-5153, doi:10.5194/acp-9-5131-2009, 2009. 